\title{
Yangtze project dammed with faint praise
}

\section{Hong Kong}

THE credibility of Chinese scientists and engineers was called into question during a surprisingly public debate that preceded approval earlier this month of the longplanned Three Gorges Dam on the Yangtze River. Critics of the undertaking, said to be the world's largest hydroelectric project, have raised doubts about the ability of the country's technical community

Tony waltham

\section{IMAGE UNAVAILABLE FOR COPYRIGHT REASONS}

Plan to dam Qutang Gorge inflames critics

to carry out such a massive undertaking safely, at cost and without harming the environment.

Only two-thirds of the deputies attending this month's meeting of the National Peoples' Congress voted to approved the project. Although only 177 of the 2,600 deputies actually voted no, another 664 abstained. The vote itself was held in the midst of loud protests by those who said they had not been allowed to speak their minds.

The idea of building a dam across the Yangtze at Yichang, in the central Chinese province of Hubei, goes back some 40 years. The current version was approved by China's leadership in January.

The project has three goals: to prevent flooding of the Yangtze, to improve navigation on the river and to generate power for the surrounding communities. Flooding has been a periodic threat to residents; in 1954, for example, a flood killed 30,000 people and left one million homeless. In addition, a report submitted to the Peoples' Congress by the State Council's Three Gorges Committee declared that the project "is especially important as it can protect the livelihood of the 15 million inhabitants of the Jingiiang River area".

The 185-metre-high dam will have an annual output of 84,000 million kilowatthours. It will take 18 years to complete, at a cost of 57 billion yuan (\$US10,000 million). Just under half the cost will be paid by those who use the power it generates, beginning halfway through the project. The rest will come from bonds and from private sources.

Opponents have focused on several negative aspects of the project. In addition to inundating 19 towns and counties and 24,000 hectares of arable land, the project will destroy a tourist region not unlike the Grand Canyon in the United States. The government says that nearly three-quarters of a million people will be forced to move from fertile farmland to much less desirable areas; critics say the figure could exceed a million.

Although international environmental organizations have been quick to criticize the project, the real surprise has been the extent of protest by deputies to the People's Congress, including the former viceminister for water conservancy, Li Rui, and the former deputy director of state planning, Tian Fang.

The level of anger is especially high in Sichuan province, which is upstream of the dam. Provincial leader Zhang Haoruo, who ultimately supported the project, nevertheless says that it will damage historical sites. Some scientists have suggested that a series of smaller dams could curb flooding and provide power without causing nearly as much damage to the environment as the Three Gorges project.

Critics have also told government officials that they expect to be kept informed of all potential problems. "We Sichuan people, on the whole, support the dam", says Nie Rong-Gui, deputy secretary of the provincial communist party committee. "But problems such as reservoir siltation, mass resettlement and environmental impact have been exposed, and we hope that the central government will adopt serious measures to solve them so that we can all feel at ease."

Some of these issues were discussed in a report that was issued by the ministries of energy and water but withheld from deputies to the Peoples' Congress. One author, Wang Zen, a researcher at China's Forestry Society, spoke critically about the extensive logging that the project would require.

Government officials have not decided when to begin construction, but they expect the debate to continue. "In some year of the 1990s the project will be formally launched", says Yang Zhenhuai, the minister of water resources. "In the preparatory work and even during construction, all suggestions and opinions from different parties will be treated earnestly and respected." Peter Gwynne, with You Qin Li, Beijing

\section{Bad timing for BU's stock gamble}

WALL Street has given a thumbs down to Boston University president John Silber's controversial decision to put nearly $\$ 100$ million of university money in a biotechnology startup.

Seragen Inc., the Hopkinton, Massachusetts, biotechnology company that BU has built up with capital and loans, decided to go public after seeing some of the hugely successful stock sales of last year (see Nature 356, 183; 1992). But by the time the Seragen stock went on sale earlier this month, Wall Street had turned away from the industry (see accompanying chart) and the company was forced to reduce its asking price from $\$ 17-\$ 20$ per share to $\$ 12-\$ 14$. Instead of $\$ 60$ million, Seragen raised only $\$ 36$ million. And the price of the stock has continued to drop; last week it stood at $\$ 9.50$.

Those numbers are bad news for BU and the mercurial Silber, who has risked the equivalent of one-fifth of the university's endowment in the company. Silber hoped that the public offering (the sale of three million shares represented a quarter of the company) would be successful enough to allow BU to stop spending $\$ 1.2$ million of its endowment each month to keep Seragen

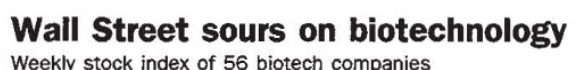

Weekly stock index of 56 biotech companies 29 December $1989=100$

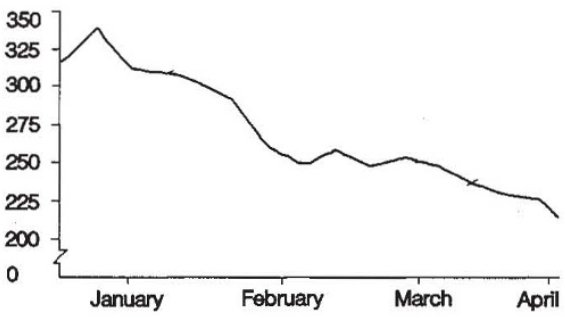

Alex Brown \& Sons, Inc running. The university still owns 69 per cent $(8.3$ million shares) of the company. But at $\$ 9.50$ a share, that stake is worth just $\$ 78$ million - \$20 million less than BU's investment.

Despite the dis a p o int ing results, BU still plans to end its monthly subsidies to the company, prompted in part by an order from the Massachusetts Attorney General to reduce the stateowned university's risk. That means that Seragen must find other sources for the capital it will need until its first products - fusion toxins for cancer and autoimmune disease therapies - appear on the market in another two or three years.

Christopher Anderenn 